(C) 2019 by the Arizona Board of Regents on behalf of the University of Arizona. This is an Open Access article, distributed under the terms of the Creative Commons Attribution licence (http://creativecommons. org/licenses/by/4.0/), which permits unrestricted re-use, distribution, and reproduction in any medium, provided the original work is properly cited.

\title{
THE RISE AND FALL OF A PARALLEL-WALLED STRUCTURE: ASSESSING THE SITE SEQUENCE AT PACHAMTA
}

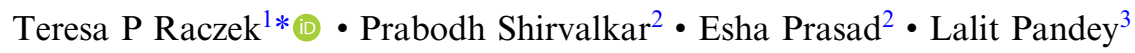 \\ ${ }^{1}$ Kennesaw State University, 402 Bartow Ave., Kennesaw, GA 30144, USA \\ ${ }^{2}$ Department of A.I.H.C. and Archaeology, Deccan College Postgraduate and Research Institute, Pune 411006, India \\ ${ }^{3}$ Faculty of Education and Technology, Jayoti Vidyapeeth Women's University, Jaipur, Rajasthan, India
}

\begin{abstract}
In this article, we investigate the chronology of a large parallel-walled mudbrick structure at the site of Pachamta in Rajasthan, India. Pachamta is larger than the contemporaneous Harappan site of Kalibangan and part of a society collectively known as the Ahar Culture. Recent excavations at Pachamta provided an opportunity to elaborate on the available dates for this society and to investigate the chronology of an enigmatic parallel-walled structure. The chronology and function of such prominent structures remains murky, although scholars have suggested that these buildings served as public storage because they resemble the granary at Harappa. Through excavation, our team collected data for assessing the Pachamta parallel-walled structure including construction methods, process of abandonment, and associated dates. The thirteen ${ }^{14} \mathrm{C}$ assays from the site and an associated phase and sequence model performed in OxCal 4.3 demonstrate that the building was constructed, used, and abandoned in a relatively brief period. If parallel-walled structures are storage buildings, then expansion of the building may indicate prosperity or surplus, while abandonment may indicate an end to abundance or a shift in resource management. Carefully dating the structure allows us to investigate the timing of social processes including political and economic shifts within the settlement.
\end{abstract}

KEYWORDS: architecture, chronology, Copper Age.

\section{INTRODUCTION}

The first farming communities of the Mewar Plain in Rajasthan, India, date to the third and second millennia $\mathrm{BC}$, roughly contemporaneous with many sites of the nearby Indus Civilization (see Figure 1). At that time, hundreds of permanent settlements in the Mewar region produced crafts, engaged in local and long-distance trade and exchange, and practiced agro-pastoralism supplemented by hunting and gathering (Raczek 2016). Often known collectively as the Ahar Culture or Ahar-Banas Cultural Complex, the sites have rarely been chronometrically dated, and internal chronologies for this society have been extrapolated from just a few ${ }^{14} \mathrm{C}$ dates (Shinde 2010; Sarkar and Shinde 2011; Sarkar 2013). Dating specific features, structures, and artifacts across this region has also posed challenges. For example, large settlements like Gilund and Pachamta shared a common feature: a large parallel-walled mudbrick structure whose chronology and function remains murky. Recent excavations at the site of Pachamta provided an opportunity to investigate the chronology of the parallel-walled structure and to add to the bank of calibrated radiocarbon $\left({ }^{14} \mathrm{C}\right)$ dates available for this society. Pachamta is a substantial site with five mounds and it is larger than the contemporaneous Harappan site of Kalibangan located $500 \mathrm{~km}$ to the north. Throughout the excavation, our team collected data for assessing the methods of construction of the parallel-walled structure as well as phases of use, method of abandonment, and associated dates. The $13{ }^{14} \mathrm{C}$ assays from the site presented below demonstrate that the building was constructed, used, and abandoned in a relatively brief period of time. This find is consistent with other architectural features, specifically, the laying of a series of plaster floors in a later period of occupation, which were also deposited in a tight timeframe.

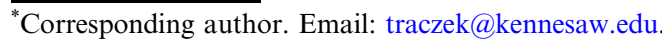




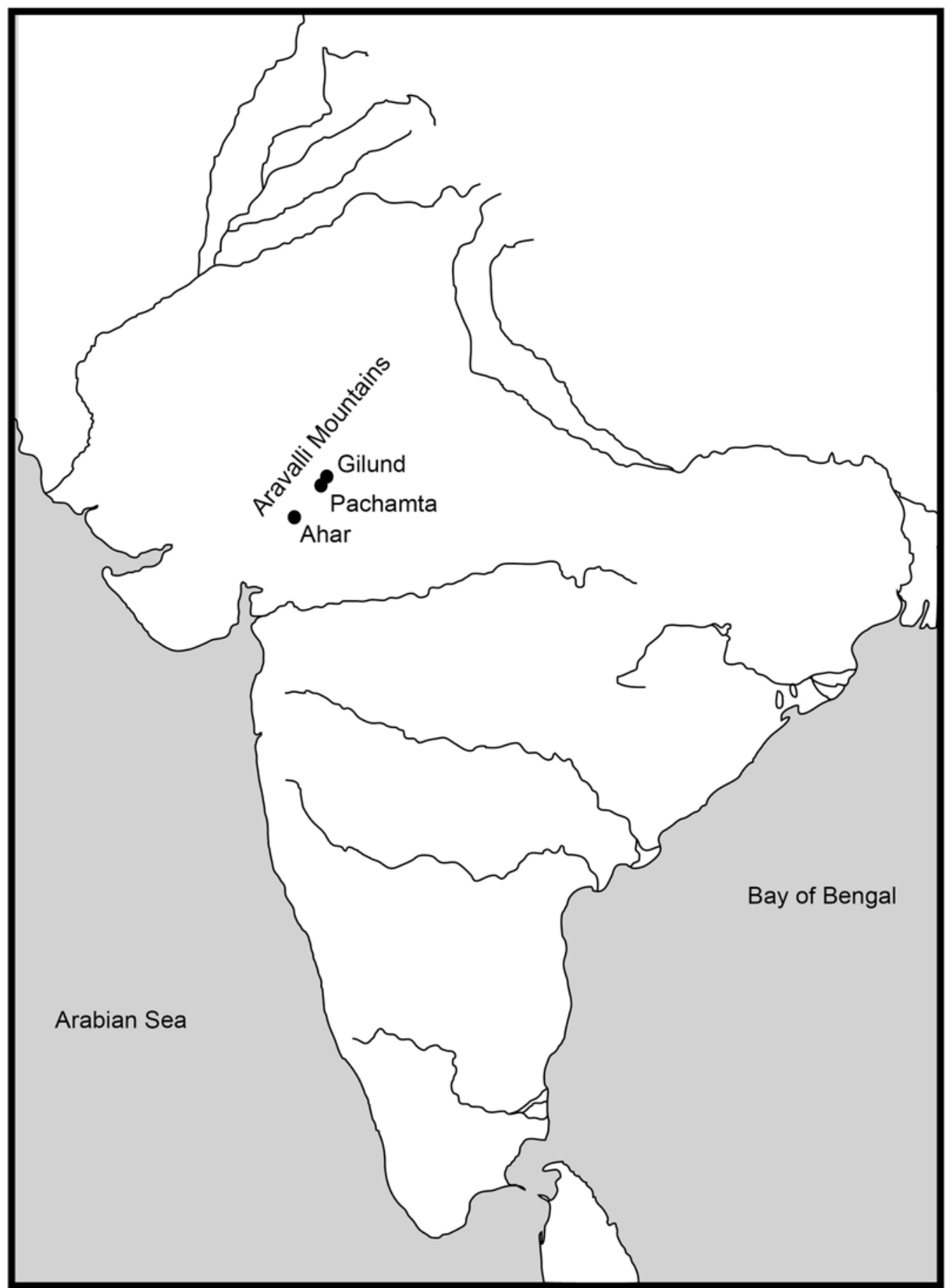

Figure 1 Map of sites mentioned in text. 
The parallel-walled structure uncovered at Gilund was identified as an example of monumental architecture (Shinde et al. 2014b). Discovered during the initial excavation of the site (Ghosh 1960: 41-46), it was further exposed in later research projects (Shinde and Possehl 2014b). Although neither excavation fully identified all of the edges of the mudbrick structure, they did expose a $20 \times 10 \mathrm{~m}$ area, indicating that the full building must have been quite large. The main part of the Gilund structure consists of 4 plastered parallel walls, set about $1 \mathrm{~m}$ apart that run north-south. They are enclosed on the north and south sides by east-west running walls. Storage pits lined with plaster are located in an additional wall or platform to the east. Additional storage bins were uncovered in the north section, which includes three parallel walls, also about $1 \mathrm{~m}$ apart. The structure had been built in two phases on a thick platform of rammed clay mixed with brick fragments. When the structure was abandoned, the spaces between all of the walls had been filled in with clean sand that contained few artifacts. Unfortunately, the excavators were not able to obtain viable carbon samples from the context of the structure, and therefore it was not directly dated. Because of its relation to areas of the site that have been chronometrically dated, they conclude that the structure dates to the Middle Chalcolithic (2500-2000 BC) (Shinde and Possehl 2014a).

The excavators at Gilund argued that the building was a "public' structure" and a "warehouse/ magazine" where elites stored and controlled valuables (Shinde and Possehl 2005: 298). They pose this argument because the narrow areas between the walls resembled documented magazines that stored unstable vessels like amphorae, that needed to lean against supporting walls (Possehl et al. 2004; Shinde et al. 2005). As one of the bins included hundreds of unbaked clay seal impressions and sealings with geometric designs (Ameri 2014), the excavators further suggested that goods stored in the building may have been taxed and that the building served an administrative function (Shinde et al. 2005: 163). They also compare the building to the granary on Mound F at Harappa, which was also originally described as "the area of parallel walls" (Shinde and Possehl 2005: 298).

At Pachamta we found a series of plaster floors and bins in the upper levels of mound I and the parallel-walled mudbrick structure in the lower levels. The structure had been built in multiple phases and was interspersed with platforms and plaster lined bins. Twelve walls run east-west and sit about $1 \mathrm{~m}$ apart. Six adjoining walls run north-south. An examination of the wall joins and abutments suggests that the structure was built in three phases. Some gaps between walls had later been filled in with mudbricks to make platforms, while other gaps were converted to bins. Ten bins, both rectangular and round, were lined with plant material (potentially cow dung) and had been reused many times. Most were filled with large pieces of bone and pottery as well as large clumps of levigated clay and the remains plain, unmarked sealings. This suggests that sealing activities similar to those at Gilund were conducted at this site. One wall had clearly partially collapsed and was later rebuilt with recycled mudbricks. Some walls still showed evidence of a lime plaster coating. While there was a thin trash layer at the base of the walls, this was topped with deep sand that included few artifacts, suggesting that the areas between the walls had been filled in deliberately in a single episode shortly after the building had been abandoned, similar to the pattern that had been noted at Gilund.

The artifacts associated with the structure did not provide sufficient evidence to indicate function. However, we suggest that a careful analysis of the chronology of construction, use, and abandonment can contribute to our understanding of these enigmatic buildings. If 
such structures are public buildings that are used for storage and administration, then expansion of the building can indicate a time of prosperity, while abandonment can indicate political or economic shifts within the settlement. By carefully dating the structure, we hoped to understand these social processes and connect them to other regional processes, both social and environmental.

\section{METHODS: SAMPLING AND ANALYSIS}

As the contemporary village of Pachamta has been built on top of the archaeological mounds, some parts of the site have extensive modern encroachments, particularly the east side of mound 1 (see Figure 2). To take advantage of the exposed stratigraphy visible in the encroachment, we excavated the upper area of mound 1 in season 1 (2015) and the lower area of the same mound in season 2 (2016). Our excavations in 2015 focused on uncovering a series of plaster floors and related bins, chulhas (hearths), and walls. During the last few days of those excavations, we identified the parallel-walled structure and so our excavations in 2016 focused on exposing those remains, assessing the construction techniques, and determining the sequence and dates of this structure and the surrounding area.

In order to assess the chronology of occupation at Pachamta and the parallel-walled structure itself, we selected upper mound samples from Trench $-\mathrm{XC} 2$, an area that included six layers and 13 plastered floors as well as a plastered bin. Three samples were collected between floors (sample 413374 in Layer 3, sample 413383 in Layer 4, and sample 413382 in Layer 5), two samples $(413375,413380)$ were collected from a bin, and one sample (413381) was collected from the fill in the burn layer, Layer 6 (see Figure 3). Two additional samples were taken from other areas of the upper mound $(413376,413384)$.

The lower mound samples were all collected from various locations in the large parallelwalled mud-brick structure (see Figure 4) in order to assess the construction sequence and determine how long the structure was in use. Three samples were taken from the area between walls 6 (Phase I) and 8 (Phase I) as this area included the deepest excavation as well as the base of a wall. In this area, one sample was taken below wall 8 in layer 11 (and therefore predates the wall), while the other two were taken in layers 9 and 10, a context with large fauna and pottery, located at the base of the wall, and below the single episode filling of the structure (and thus postdates the wall construction, but predates the filling of the structure). One sample was taken between walls 13 (Phase I) and 16 (Phase I) in layer 12, just underneath bin 8 (Phase III) and at the base of wall 16 (Phase I) (which is also located under the bin as the bin cut the wall). Finally, one date was taken from a feature that consisted of ash and a cluster of large animal bones in layer 12 between walls 16 (Phase I) and 17 (Phase II).

We submitted 13 samples to the Beta Analytic lab in Florida, USA: 8 samples for season 1 and 5 samples for season 2 (see Table 1). All samples consisted of unidentified charred material (charcoal); eleven were run with AMS, and two with radiometricPLUS. All dates were calibrated using the INTCAL 13 calibration curve (Reimer et al. 2013), Betacal 3.21 calibration software, and the High Probability Density Range Method. The dates are consistent; deeper layers are earlier and the date range for each layer overlaps slightly.

To obtain a refinement of the dates, we used OxCal 4.3 software to create a model that combined simple sequences and phases (Bronk Ramsey 2008, 2009). The main sequence included two phases, each with their own sequence: Lower Mound (Layers 7-13) and 


\section{Pachamta 2015-16}
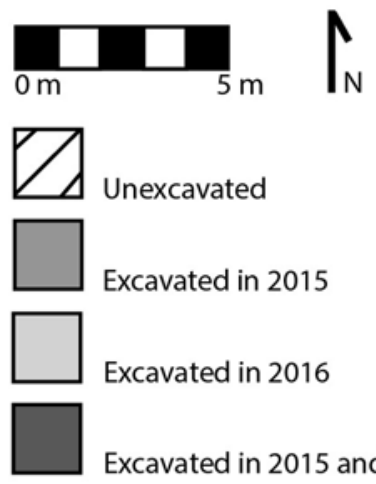

Excavated in 2016

Excavated in 2015 and 2016

Edge of encroachment

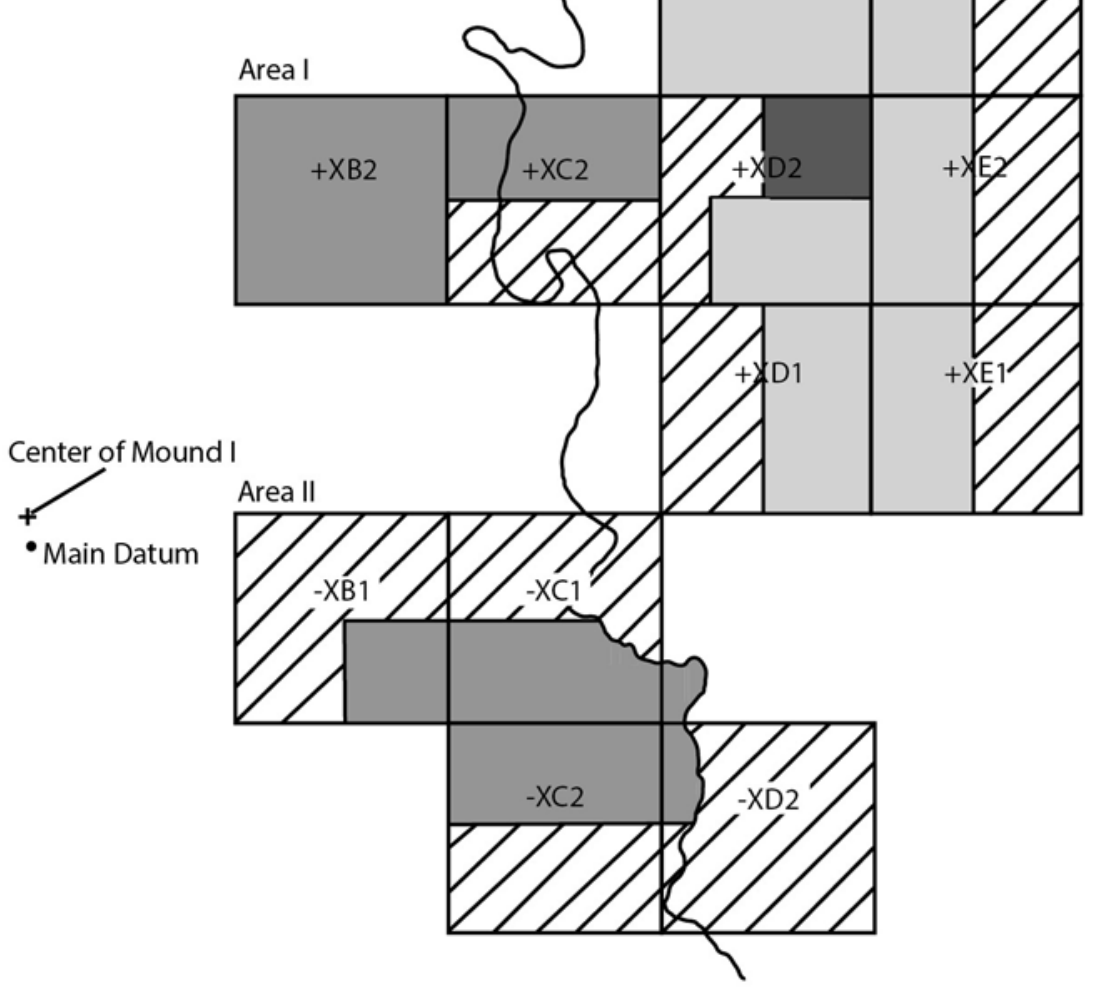

Figure 2 Areas of excavation at Pachamta.

Upper Mound (Layers 1-6). The Lower Mound sequence included four dates and the Upper Mound sequence included six dates. We separated the samples into two phases in part because the burn layer between the upper and lower mound (Layer 6) seemed to mark a significant event on the mound. In addition, the Upper Mound samples were taken from a trench that 


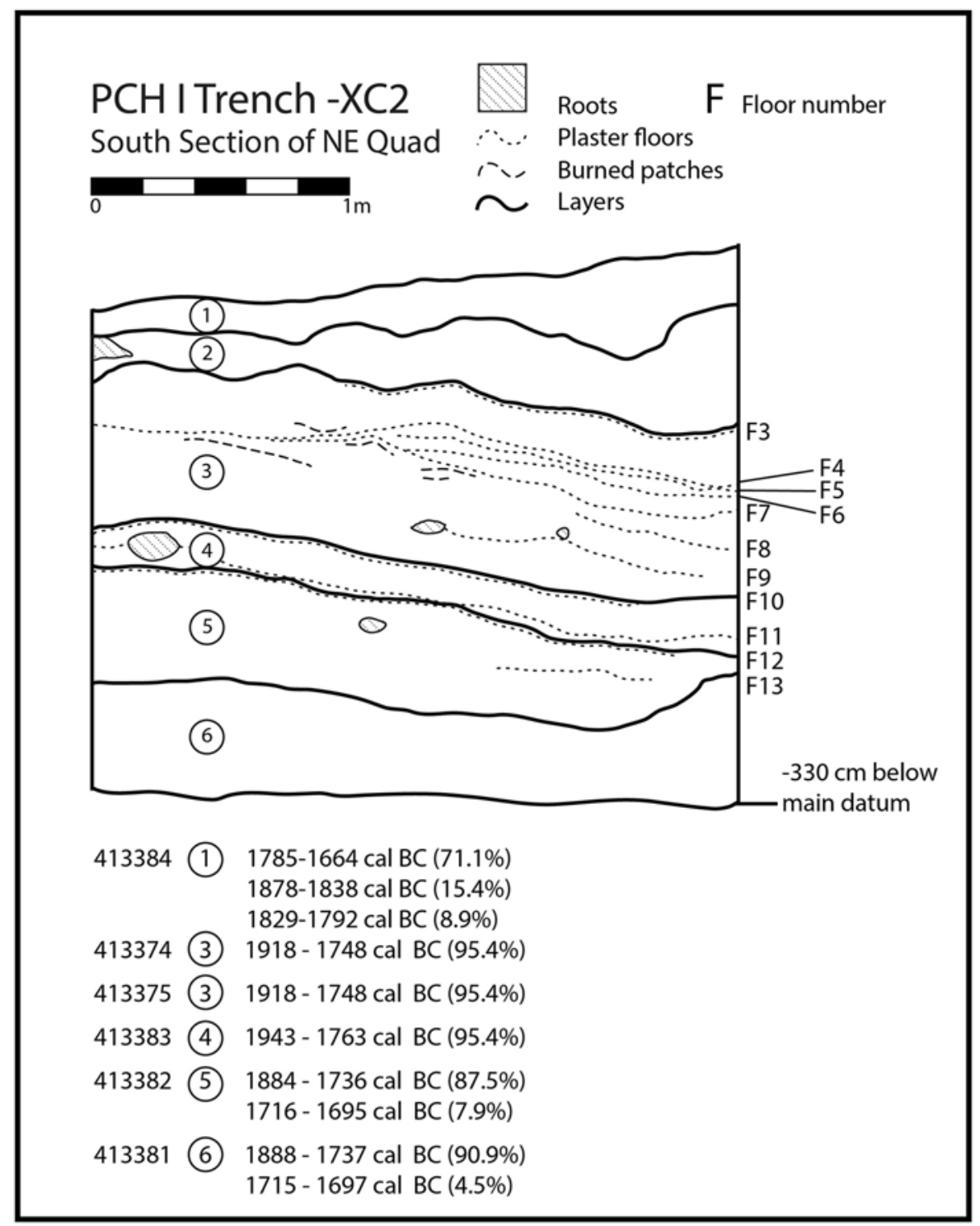

Figure 3 South profile of $-\mathrm{XC} 2$ with calibrated ${ }^{14} \mathrm{C}$ samples from this area.

was $5 \mathrm{~m}$ or more south of the Lower Mound samples. Further, the encroachment and resulting erosion as well as our excavation strategy precluded our ability to excavate the point where layers 6 and 7 meet. However, we combined the dates in a single model as the Upper and Lower Mounds are clearly related. We excluded three dates that came back as outliers in the initial run of the program. Of these, one date from the Lower Mound may be intrusive (496498), one date from the Upper Mound came from Layer 1 of a separate trench from the other Upper Mound dates (413376), and one date came from a bin capped by Layer 3, a stratigraphically complex location (413380). The results are presented in Table 2 and Figure 5. 


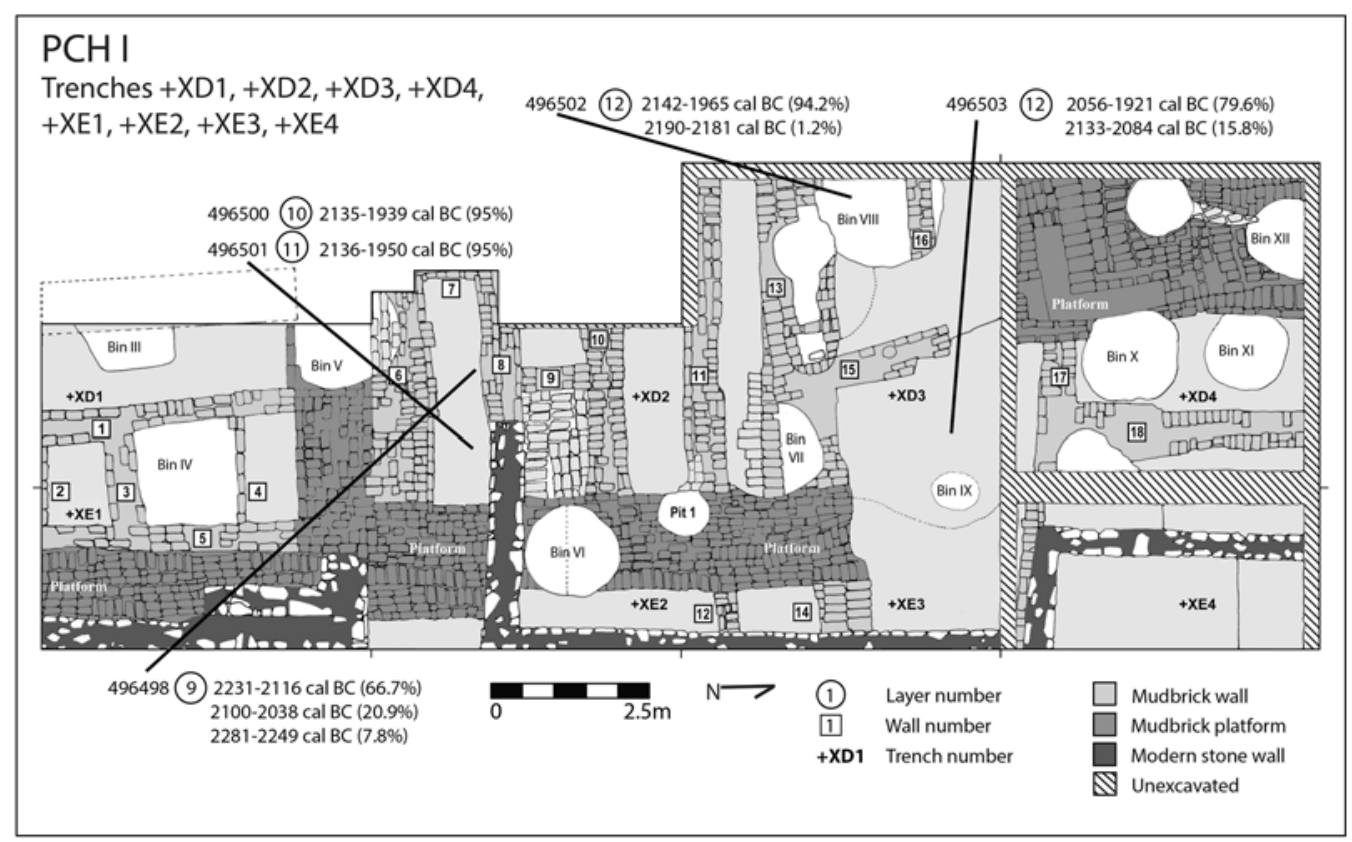

Figure 4 Pachamta parallel-walled structure with calibrated ${ }^{14} \mathrm{C}$ samples from this area. (Drawing by Bharat Dighe and Devadatta Phule.)

\section{RESULTS: RADIOCARBON ASSAYS AND CALIBRATED PROBABILITY DISTRIBUTIONS}

The OxCal model refines some of the dates and provides a potential start date for the lower mound phase of 2266 cal BC-1977 cal BC. Approximately 3-4 m of unexcavated deposition remained beneath our deepest sample, so we expect that the mound was originally occupied in the mid-third millennium BC. The boundary between the lower and upper mound phases is modeled at 2001-1801 cal BC and the end of the upper mound phase is modeled at about 1874 cal BC-1636 cal BC.

All of the upper mound dates are tightly clustered in the early to mid-second millennium BC before and after modeling. This indicates that the floors in this area were potentially made and remade in a span of about 150 years or less. The bin in this area that is capped by layer 3 and intrudes in to layers 4, 5, and 6 dates to the same time frame as layer 3 . The burn layer (Layer 6 ) is only slightly earlier.

These results also suggest that the parallel-walled structure was constructed and used around the turn from the third millennium $\mathrm{BC}$ to the second millennium $\mathrm{BC}$ and then quickly abandoned. The clear building episodes seen in the wall construction occurred in a tight timeframe. Sample 496501 from layer 11 below wall 8 dates to roughly 2136-1950 cal BC (or 2102-1946 cal BC after modeling). The construction of that wall postdates that sample but predates sample 496500, which was recovered from a thin lens of broken bricks and trash just above the base of the wall and dates to 2136-1939 cal BC (2032-1921 cal BC after modeling). After the building was no longer in use, this trash lens was deposited and then the space between the walls was deliberately filled with a fine sand layer that included only one artifact, a sherd which presumably got mixed in during the filling process. Sample 496498, a piece of charcoal from that fine sand fill layer (Layer 9), produced unclear dates 
Table 1 Radiocarbon dates and calibration from Pachamta.

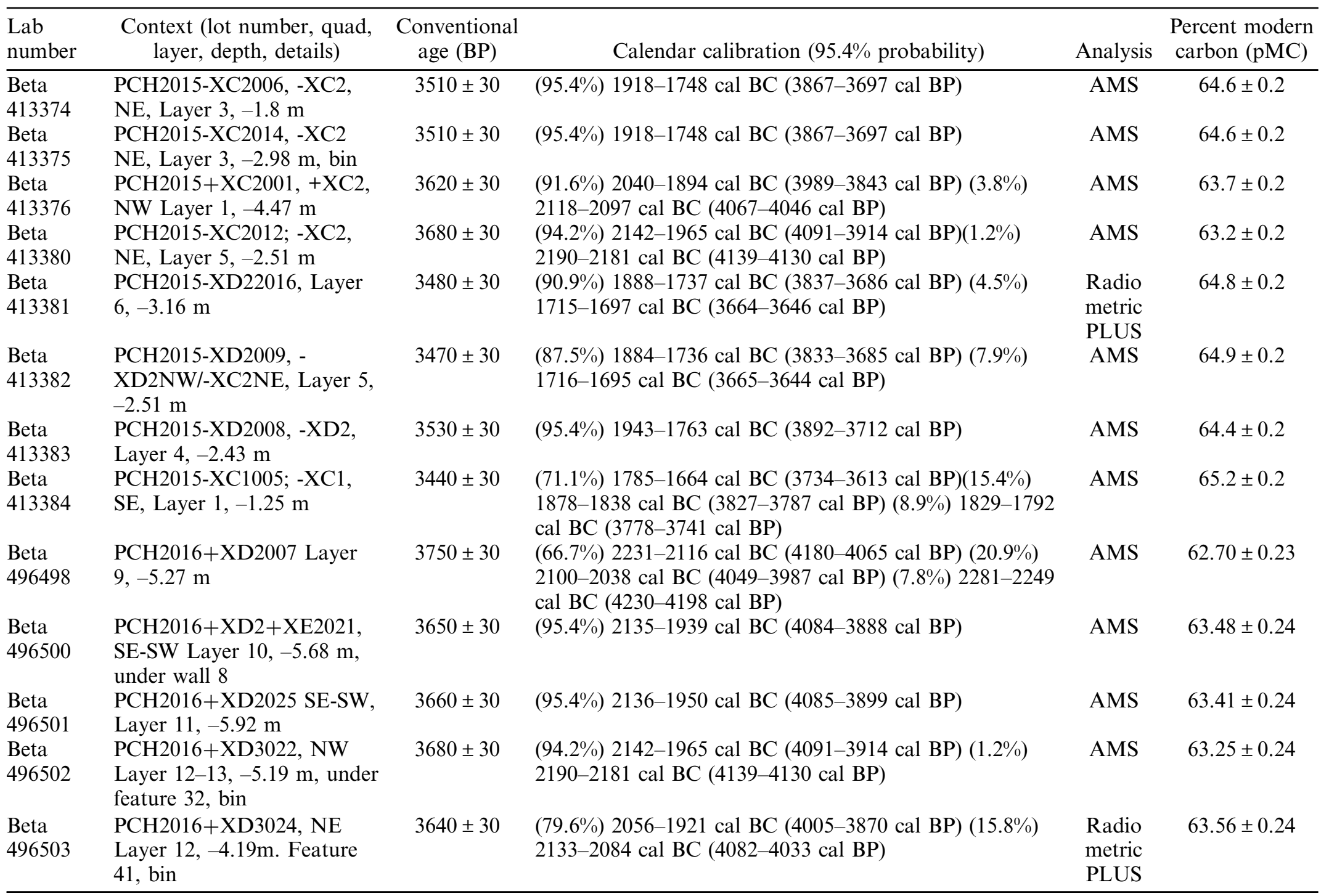

413380

Beta

PCH2015-XD22016, Layer

PCH2015-XD2009,

W/-XC2NE, Layer 5

413383

Beta

PCH2015-XC1005; -XC1,

ayer $1,-1.25 \mathrm{~m}$

\section{Beta $\quad$ PCH2016+XD2007 Laye}

\section{Beta} under wall 8

496501

\section{Beta}

PCH2016+XD3022, NW

PCH2016+XD3024, NE

41, bin 
Table 2 Modeled dates from Pachamta.

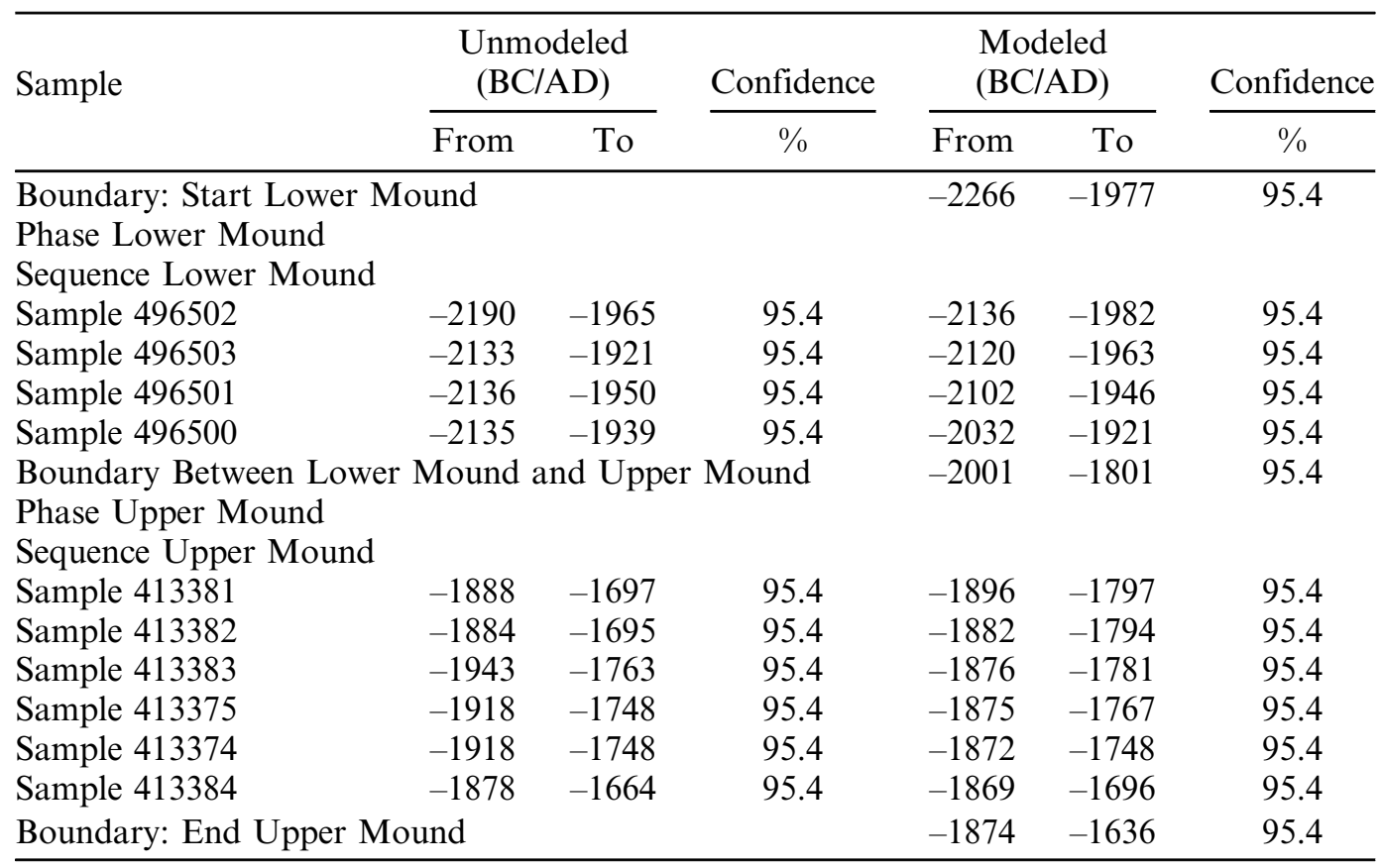

because of its location on the carbon curve. As the charcoal was mixed with the fill sand, it may date to the time of the wall filling or some period prior to that. Because of these issues and because the sample was an outlier, it was removed from the model.

In another area of the structure, we focused on bin 8 (Phase III), which was created after the building had been filled when the occupants dug into deeper layers as well as wall 16 (Phase I). We collected sample 496502 in a small space underneath bin 8 (Phase III) and on top of wall 16 (Phase I). As a result, we argue that it dates to the time before or during the construction of bin 8 (Phase III) and it postdates the construction of wall 16 (Phase I). The sample dates to 2142-1965 cal BC $(94.2 \%)$ or 2190-2181(1.2\%) cal BC (2136-1981 cal BC after modeling). These dates are tightly clustered with those described above, suggesting that the bin construction occurred not long after the building was built and then filled in.

In an area just east of bin 8 (Phase III), Sample 496503 was taken from feature 41, a cluster of large cattle bones and charcoal that appear to be a single dumping episode in layer 12. It dates to 2056-1921 cal BC (79.6\%) or 2133-2084 cal BC (15.8\%) (or 2120-1962 cal BC after modeling). This episode postdates the wall construction and falls roughly in the same time frame as the bin construction.

Finally, Sample 413381 from layer 6, the burn layer, dates to $1888-1737$ cal BC $(90.9 \%)$ or 1715-1697 cal BC (4.5\%) (or 1896-1797 cal BC after modeling). The burning postdates the filling in of the parallel-walled structure and the bins. As the dates are close to the other samples, we suggest that the burn episode may have occurred as early as one or two generations after the building use was discontinued. There is no evidence that burning caused the building to be abandoned. 


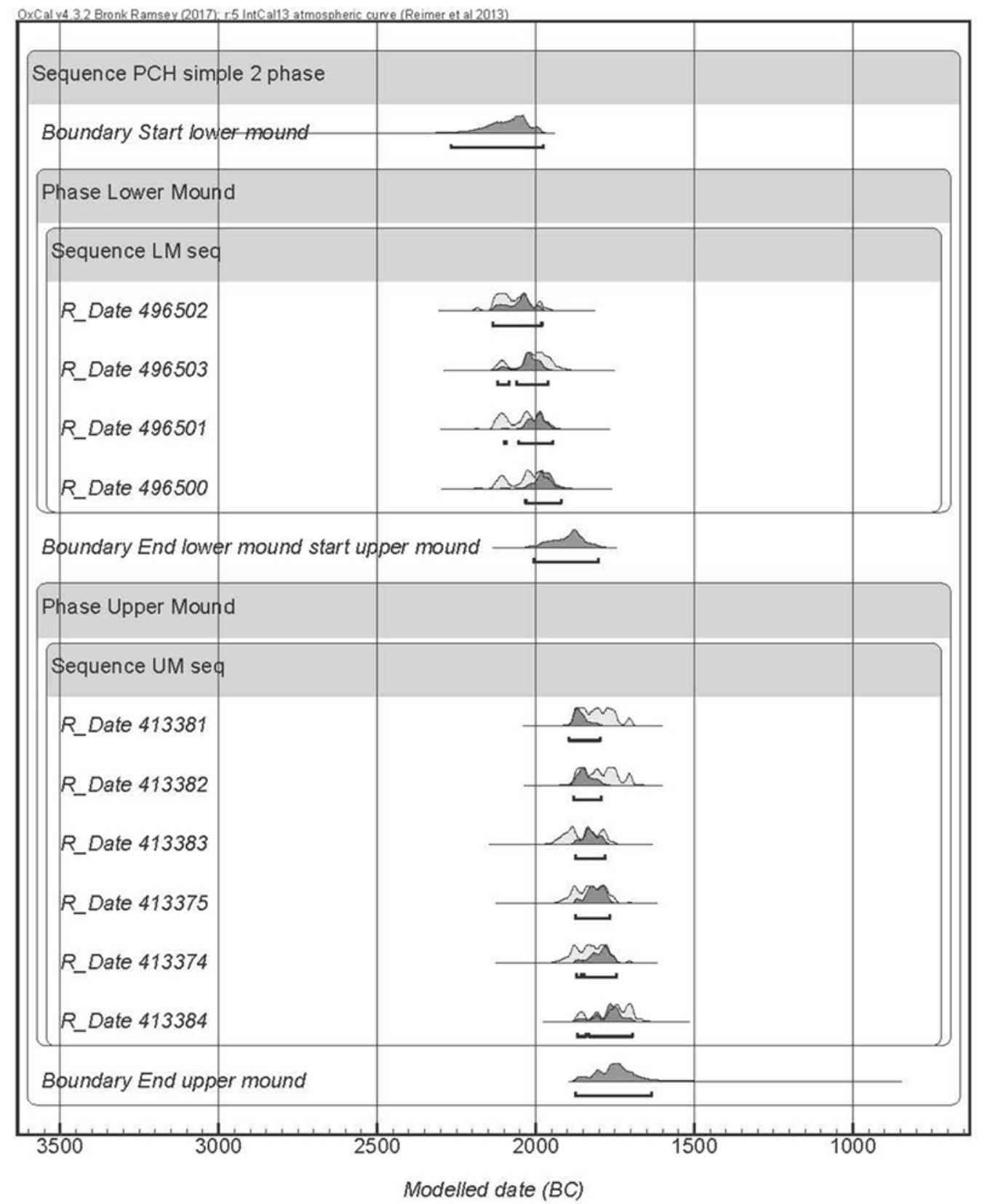

Figure 5 Multiplot of phase and sequence analysis.

\section{DISCUSSION AND CONCLUSION}

The dates presented here roughly align with other Chalcolithic sites across the Mewar Plain, including Ahar Period IB (Kusumgar et al. 1963a, 1963b; Bermingham 1966; Sankalia et. al. 1969) and Balathal Phase B (Misra 2005). The dates also align with those from Pachamta's nearest neighbor Gilund (Shinde et al. 2014b: 237). Although we did not excavate to sterile 
soil, we estimate that Mound 1 may have been established in the mid-third millennium BC. The assays presented here show that the parallel-walled structure was most likely built some time shortly before or after $2000 \mathrm{BC}$ and abandoned before the burning event that took place between roughly 1900 and $1700 \mathrm{BC}$. In fact, if the building was built as late as $1945 \mathrm{BC}$, its use may have been discontinued within a generation, although if it was built earlier, it may also have been used for as much as 150 years, the span of 2-3 lifetimes. The Pachamta parallel-walled structure may be contemporaneous with or later than the one at Gilund, since that structure had been relatively dated to 2500-2000 BC. Like the building at Gilund, the one at Pachamta was constructed on a dense clay layer and deliberately backfilled with fine sand. Several areas between the walls were used as bins not long after the building was constructed. If the building was used as a warehouse for the storage of goods, then the quick expansion may indicate a boom in production or collection of goods as well as an expanding economy in general. Whether this material success is limited to a single family or group who built and used the structure, or suggests a broader prosperity remains unclear. This expansion may have been short-lived, however, as the building was quickly transformed and abandoned. The connection of this sequence of events to other ongoing social and economic processes in the region as well as shifts in climate should be further investigated. As we only excavated a small portion of one of the five mounds at Pachamta, we hope that future excavations can refine the chronological sequence that we present here.

\section{ACKNOWLEDGMENTS}

We thank the Archaeological Survey of India for granting excavation permits and permission to run the dates at Beta Analytic. We thank our funders: the National Geographic Society, Kennesaw State University Division of Global Affairs, Deccan College Postgraduate and Research Institute, Institute for Rajasthan Studies, and Rajasthan Vidyapeeth University. We thank the American Institute of Indian Studies for logistical assistance. We especially thank the excavators and supporters of Pachamta, particularly Bharat Dighe and Devadatta Phule. We thank Ron Hatfield from Beta for reviewing the dates from Pachamta with us, the creators of the OxCal calibration software for making the software available to the public for free, Christopher Bronk Ramsey for answering questions about the software, and two anonymous reviewers who provided very helpful comments.

\section{REFERENCES}

Ameri M. 2014. Report on the seal impressions and related small finds. In: Shinde VS, Raczek, TP, Possehl GL, editors. Excavations at Gilund: the artifacts and other studies. Philadelphia: University of Pennsylvania Museum of Archaeology and Anthropology. p. 157-209.

Bermingham A. 1966. Victoria natural radiocarbon measurements I. Radiocarbon 8:507-521.

Bronk Ramsey C. 2008. Deposition models for chronological records. Quaternary Science Reviews 27(1-2):42-60.

Bronk Ramsey C. 2009. Bayesian analysis of radiocarbon dates. Radiocarbon 51(1):337-360.

Ghosh A, editor. 1960. Indian archaeology: A review 1959-60. New Delhi: Archaeological Survey of India. p. 41-46.

Kusumgar S, Lal D, Sarna RP. 1963a. Tata Institute radiocarbon date list I. Radiocarbon 5: 273-282.

Kusumgar S, Lal D, Sarna, RP. 1963b. Radiocarbon dating: Results. Indian Academy of Science 58(3):141-152.

Misra VN. 2005. Radiocarbon chronology of Balathal, District Udaipur, Rajasthan. Man and Environment 30(1):54-60.

Possehl GL, Shinde V, Ameri M. 2004. The AharBanas Complex and the BMAC. Man and Environment 29(2):18-29.

Raczek, TP. 2016. The Ahar Culture and others: Social spectrums of the Mewar Plain. In: Robbins Schug G, Walimbe SR, editors. A companion to South Asia in the past. Malden (MA): Wiley Blackwell. p. 225-239. 
Reimer PJ, Bard E, Bayliss A, Beck JW, Blackwell PG, Bronk Ramsey C, Grootes PM, Guilderson TP, Haflidason H, Hajdas I, Hatt ŽC, Heaton TJ, Hoffmann DL, Hogg AG, Hughen KA, Kaiser KF, Kromer B, Manning SW, Niu M, Reimer RW, Richards DA, Scott EM, Southon JR, Staff RA, Turney CSM, van der Plicht J. 2013. IntCal13 and Marine13 radiocarbon age calibration curves $0-50,000$ years cal BP. Radiocarbon 55(4):1869-1887.

Sankalia HD, Deo SB, Ansari ZD. 1969. Excavations at Ahar (Tambavati). Pune: Deccan College Postgraduate and Research Institute.

Sarkar, A. 2013. Contextualizing Ahar Culture phase in central India. In: Rag P, Shinde V, Misra OP, editors. Art and archaeology of Madhya Pradesh and adjoining regions: Recent perspectives. Bhopal: Directorate of Archaeology, Archives \& Museums, Government of Madhya Pradesh. p. $163-173$.

Sarkar A, Shinde V. 2011. Development of Chalcolithic phases in Gilund through ceramic chronology. Iranian Journal of Archaeological Studies 1(2):61-73.

Shinde V. 2000. Origin and development of the Chalcolithic in central India. Indo-Pacific Prehistory Association Bulletin 19:125-136.

Shinde V. 2010. Cultural development from Mesolithic to Chalcolithic in the Mewar region of Rajasthan, India. Pragdhara 18:210-213.

Shinde V, Possehl GL. 2005. A report on the excavations at Gilund, 1999-2001. In: Jarrige C, Lefèvre V, editors. South Asian archaeology
2001. Paris: Éditions Recherche sur les Civilisations. p. 293-302.

Shinde V, Possehl GL. 2014a. Excavations methods and stratigraphy. In: Shinde V, Raczek TP, Possehl GL, editors. Gilund excavations: The artifacts and other studies. Philadelphia: University of Pennsylvania Museum of Archaeology and Anthropology. p. 11-24.

Shinde V, Possehl GL. 2014b. Chalcolithic structures and features. In: Shinde V, Raczek TP, and Possehl GL, editors. Gilund excavations: The artifacts and other studies. Philadelphia: University of Pennsylvania Museum of Archaeology and Anthropology. p 25-44.

Shinde V, Possehl GL, Ameri M. 2005. Excavations at Gilund 2001-2003: The seal impressions and other finds. In: Franke-Vogt U, Weisshar H-J, editors. South Asian Archaeology 2003. Bonn: Kolloquiem zur Allgemeinen und Vergleichenden Archaologie. p. 155-165.

Shinde V, Raczek TP, Possehl GL. 2014a. Synthesizing Gilund: A summary and discussion of excavation finds. In: Shinde V, Raczek TP, Possehl GL, editors. Excavations at Gilund: The artifacts and other studies. Philadelphia: University of Pennsylvania Museum of Archaeology and Anthropology. p. 231-235.

Shinde V, Raczek TP, Possehl GL. 2014b. Appendix 1: Radiocarbon dates for Gilund. In: Shinde V, Raczek TP, Possehl GL, editors. Excavations at Gilund: The artifacts and other studies. Philadelphia: University of Pennsylvania Museum of Archaeology and Anthropology. p. 1-10. 